Review article

\title{
Tomato fruit quality in relation to water and carbon fluxes
}

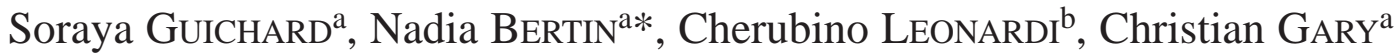 \\ ${ }^{a}$ Unité de Bioclimatologie, INRA, Domaine St-Paul, Site Agroparc, 84914 Avignon Cedex 9, France \\ ${ }^{\mathrm{b}}$ Dipartimento di Agrochimica e Agrobiologia, Reggio Calabria University, Piazza S. Francesco, Gallina, 89061, Italy
}

(Received 15 November 2000; revised 16 March 2001; accepted 20 March 2001)

\begin{abstract}
This review is about the involvement of the water and carbon fluxes in the formation of tomato fruit quality. This approach has provided new insights that help in understanding and controlling some of the major variables of fruit quality. Variations in the concentration of dry matter and sugars have been coupled with the conditions of climate and root medium: these concentrations increase under high radiation, high vapour pressure deficit (VPD) or high nutrient concentration. Dry matter and sugar concentrations would not be affected by the availability of assimilates $\left(\mathrm{CO}_{2}\right.$ concentration or fruit load). Such increases in dry matter or sugar concentration could be associated with variations in the balance between water and assimilate influx to the fruit i.e. between the fluxes of the phloem and xylem saps and of fruit transpiration. Similarly, the observed relation between the occurrence of blossom-end rot (BER) and conditions of osmotic or water stress can be explained by variations of Ca transport to the fruit by the xylem influx. Fruit cracking could be related to high variations in fruit growth and water influx under changing conditions of temperature or VPD. In contrast, acids and products of the secondary metabolism that are synthesised during the maturation stages could not be linked to the water and carbon fluxes between the plant and the fruit.
\end{abstract}

Lycopersicon esculentum Mill. / xylem / phloem / fruit quality / sugar concentration / acid concentration / BER / water status / fruit cracking

Résumé - Qualité du fruit de tomate en relation avec les flux d'eau et de carbone. Cette synthèse s'intéresse aux rôles des flux d'eau et de carbone dans la formation de la qualité du fruit de tomate. L'approche considérée a donné de nouveaux aperçus qui permettent de mieux comprendre et contrôler des variables majeures de la qualité du fruit. Les variations de concentration en matière sèche et en sucres ont été mises en relation avec les conditions climatiques et le milieu racinaire : ces concentrations augmentent sous fort rayonnement, fort déficit de pression de vapeur (DPV) ou en présence de fortes concentrations en minéraux. Les concentrations en matière sèche et en sucres ne seraient pas affectées par la disponibilité en assimilats (liée par exemple à la concentration en $\mathrm{CO}_{2}$ ou la charge en fruits). De telles augmentations des concentrations en matière sèche et en sucres ont pu être associées à des variations de l'équilibre entre les entrées d'eau et d'assimilats dans le fruit, c'est-à-dire entre les flux de sève phloémienne et xylémienne et la transpiration. De la même manière, la relation observée entre l'apparition de la nécrose apicale ou blossom-end rot (BER) et les conditions de stress osmotique ou hydrique peut être expliquée par des variations de l'apport de calcium dans le fruit par le flux xylémien. Les craquelures du fruit seraient liées à des variations importantes de la croissance du fruit et de l'entrée d'eau sous des conditions variables de température et de DPV. Par contre, les acides et les produits du métabolisme secondaire qui sont synthétisés pendant la phase de maturation, n'ont pas pu être reliés aux flux d'eau et de carbone entre la plante et le fruit.

Lycopersicon esculentum Mill. / xylème / phloème / qualité du fruit / concentration en sucres / concentration en acide / nécrose apicale / BER / état hydrique / craquelure / microfissure

Communicated by Christian Gary (Avignon, France)

* Correspondence and reprints

bertin@avignon.inra.fr 


\section{INTRODUCTION}

For several years now, fruit quality has become a major commercial concern with the setting up of labels of quality in response to increasingly demanding consumers. This involves not only criteria of visual attractiveness of fruit such as shape or colour [2, 14, 57] but also its taste and texture. In tomato, criteria such as dry matter concentration [13], sugar and acid concentration [51] or the occurrence of BER (Blossom-end rot) [6] have been studied to gain insight into the mechanisms involved in forming quality. The necessary but often oversimplifying correlations between fruit quality at harvest and growing conditions are not sufficient to be able to completely control quality during the production season. It is possible to understand and control phenomena such as physiological disorders (e.g. fruit cracking or $\mathrm{BER}$ ) only if the physiological processes involved during the growth and development of fruit are taken into account $[11,28,40,55]$.

In tomato, the size of fruit can be controlled through regulating the vegetative/generative balances during plant development $[12,31,36]$ and hence optimising the water and carbon fluxes towards the fruit. Recent studies showed that these water and carbon fluxes are also involved in forming several determining variables of fruit quality. There are three major periods in tomato development [38]: the first during which the majority of cell divisions occur, the second so-called growth phase and finally the ripening phase (Fig. 1). It is during the first phase that the growth potential of the fruit is determined via the number of cells formed. During the second phase, this potential is reached to varying degrees depending on the climatic conditions (light intensity, $\mathrm{CO}_{2}$ concentration, temperature, humidity) and the source/sink balance within the plant, whereas the third phase is essentially a phase of biochemical transformation [27] dependent on both the compounds stored previously and the environment of the fruit during ripening. Fruit quality is therefore determined continuously as it grows. The final composition of the fruit depends greatly on the inputs (of water and carbon) and the storage of assimilates throughout its development, although certain compounds are only synthesised during the ripening phase.

A ripe tomato is principally composed of water and 5 to $8 \%$ dry matter, half of which is carbohydrates, essentially glucose and fructose [17]. A quarter of this dry matter is made up of organic acids (malic and citric acids), lipids and minerals, and the other quarter of insoluble solids. However, several studies showed that it is the balance between final sugar and acid concentrations of the fruit, characterised mainly by the reducing sugar/acid or the soluble sugar/total acidity ratio, which gives tomato part of its flavour [14, 41, 51, 57]. Thus controlling the dry matter concentration of tomato is a first step towards controlling its quality.

This review summarises present knowledge on the physiological aspects of the formation of tomato quality. It focuses principally on the effects of environmental factors and cultural practices on fruit quality through their repercussions on water and carbon fluxes during fruit growth.

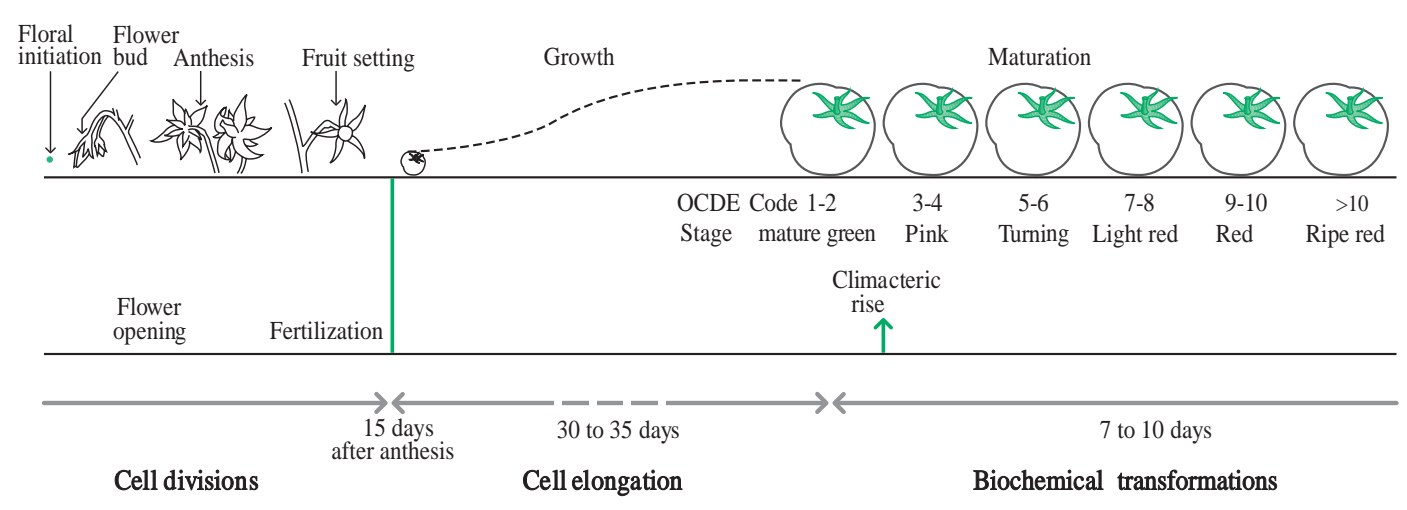

Figure 1. Main periods of tomato fruit growth and development from initiation to maturation. 


\section{EFFECTS OF WATER AND CARBON FLUXES ON THE DRY MATTER, SUGAR AND ACID CONCENTRATIONS OF FRUIT}

Although the photosynthesis of an immature tomato is not negligible [16], it is only responsible for a small part of the dry matter present in the fruit; less than $10 \%$ according to Ho and Grimbly [37]. Most of the dry matter of the fruit therefore comes from the assimilates photosynthesised in the leaves then transported to the fruit as sucrose. It is the transformation in the fruit of the sucrose and other sugars into organic acids and other aroma compounds which partly determines their taste. The origin of the acids contained in the fruit however remains uncertain. Some would seem to be synthesised in situ from carbohydrates or other acids, and some imported from the leaves or roots via the phloem $[18,54,56]$. The quantity of water present in the fruit is an essential factor for its quality since it determines the concentration of different elements such as dry matter, sugars and acids. The mechanisms which control the intake of carbon and water in the fruit therefore play an essential role in determining not only the size but also the dry matter concentration of the fruit (Fig. 2) and therefore its final quality.

Several studies showed that the dry matter concentration of tomato varies during the growing season, reaching a maximum at the beginning of summer [13-15, 61]. The sugar concentration of the fruit follows the same pattern $[15,53,61]$ whereas the total acidity decreases [53]. Since carbohydrate production by leaf photosynthesis is closely linked to the available radiation, it is not surprising that the dry matter and sugar concentrations of the fruit reach a peak in summer when the radiation flux is maximum. However, the dry matter concentration of ripe fruit cannot be explained solely by the effect of climate (light, temperature) on the activity of the source organs. For example, Ho and Grimbly [37] reported that an increase in the $\mathrm{CO}_{2}$ concentration, even if it is accompanied by an increase in the photosynthesis rate, the number and the size of the fruit, does not necessarily lead to an increase in the sugar and dry matter concentration of the fruit. In fact, the increase in the quantity of sugar imported by the fruit following $\mathrm{CO}_{2}$ enrichment is accompanied by an equivalent increase in the quantity of water entering the fruit. Thus, the size of the fruit increases without an increase of the dry matter concentration. This phenomenon would explain first the results obtained by Blanc [14] who reported that the $\mathrm{CO}_{2}$ concentration has negligible effects on the dry matter and soluble solid concentration of the fruit, and second the results obtained by Bertin et al. [13] who showed that the decrease in plant fruit load, from six to three fruits per truss, leads to an increase in the size of the fruit but not to an increase in dry matter concentration. Guichard [28] showed that decreasing plant fruit load leads to almost proportional increases of phloem and xylem water influx and transpiration efflux from the fruit. The increase in dry matter concentration of the fruit in summer would coincide with favourable conditions for the production of carbon assimilates but with a slight water stress which does not enable a proportional increase in the water flux $[36,37]$.

Other studies showed that high salinity of the nutrient solution improves tomato quality in terms of sugar and acid concentrations [3, 19, 25, 54]. In hydroponics, the dry matter concentration of the fruit increases linearly with the electro conductivity of the nutrient solution [5, 36]. In the same way, water stress applied to the crop leads to an increase in the dry matter and sugar concentrations of ripe fruit [54]. These phenomena have been explained by the fact that saline and water stress do not affect the quantity of dry matter accumulated by the fruit although they greatly reduce its accumulation of water $[21,54]$. This would lead to an increase in the concentration of dry matter and of various components (sugars, acids) of the fruit $[21,54]$. Ho et al. [39] explained this phenomenon by an increase in the phloem sap concentration as well as by a decrease in its flux, both following a reduction in the water available in the plant in the event of high salinity $\left(17 \mathrm{mS} \cdot \mathrm{cm}^{-1}\right)$. Since the phloem flux (water + carbon) is largely responsible for the increase in size of the tomato $[20,26,46]$, through its supply of water (more than $88 \%$ of the net water flux) [39, 62], the decrease of this flux accompanied by an increase in its sugar concentration results in fruit which are smaller but with a higher dry matter concentration. The dry matter and sugar concentrations of fruit exposed during their growth to high vapour pressure deficits (VPD), as is the case in Mediterranean regions during the summer season, are significantly higher than those of fruit exposed to low VPD [13, 49]. According to Guichard et al. [29], this phenomenon can be explained by a decrease in the water accumulation by the fruit without any significant modification in the quantity of accumulated sugars. These authors showed that increased VPD (from 1.0 to $2.5 \mathrm{mb}$ during the daytime) leads to a reduction in the water intake of fruit via the xylem (up to $-25 \%$ ) as well as an increase in fruit transpiration (up to $+27 \%$ ) which leads to a reduction in the net accumulation of water by the organ $(-30 \%)$. Moreover, they showed that high VPD moderately reduce the phloem flux into the fruit; less than $9 \%$ of daily phloem flux. These results are consistent with the studies conducted on the effects of high VPD on fruit transpiration [20,48, 49] as well as on the effects of strong radiation or of high VPD on the increase in transpiration of the whole plant [52], and consequently the reduction in the water content of the plant and the water potential of the stem [42, 44, 45, 47]. 
In tomato, the water potential of the fruit varies little with the environmental conditions and over time [28, 29, 42] whereas the water potential of the stem is very sensitive [42] to modifications to the water regime of the plant. The water flux from the stem towards the fruit is proportional to the water potential gradient between these two organs (Fig. 3).

\section{EFFECTS OF WATER FLUX ON BER OF FRUIT: IMPORTANCE OF THE CALCIUM FLUX TOWARDS THE FRUIT}

BER is a physiological disorder of tomato caused by calcium deficiency in the distal part of the fruit [7, 40]. The symptoms of this disorder are browny-black spots associated with tissue necrosis [27]. These symptoms generally appear at the beginning of the growth phase of the fruit and are more marked when fruit growth is rapid [27]. BER makes fruit unfit for sale as well as for storage because of the risks of infection by fungi and the occurrence of diseases.

Osmotic stress linked to high salinity in the nutrient solution [4, 35] and water stress [58] are frequent causes of calcium deficiency in fruit, more than high humidity which leads to a calcium deficiency in the leaves [32]. The use of nutrient solutions with a high salinity generally makes the calcium deficiency of fruit worse [6, 7] because it leads to reduced calcium absorption and distribution in their distal part $[6,22]$. In tomato, since calcium is transported in the plant and fruit mainly via the xylem [39, 62], this phenomenon has been explained by the effects of high salinity on the long term reduction of the growth of young xylem tissues [10], in particular in the distal part of the fruit [11]. High salinity seems to aggravate the natural strong resistance to xylem sap transfers due to the small number of xylem vessels in the abscission zone of the pedicel [46] and in the distal part of the fruit $[11,60]$.

Several studies $[13,14]$ showed that BER can also be aggravated when tomato is exposed to high VPD. These observations are in agreement with the studies conducted on the effects of air humidity on calcium absorption and distribution in the plant (leaves, fruit). In tomato, a high proportion of calcium absorbed by the plant and transported by the xylem via the transpiration stream is diverted towards the leaves rather than to the fruit because of the difference in transpiration between these two organs [35]. The calcium supply to the leaves, mainly determined by the ascending water xylem flux, would seem to be greater than that of the fruit because of their greater transpiration. This phenomenon is confirmed by Adams and Holder [8] who showed that high air

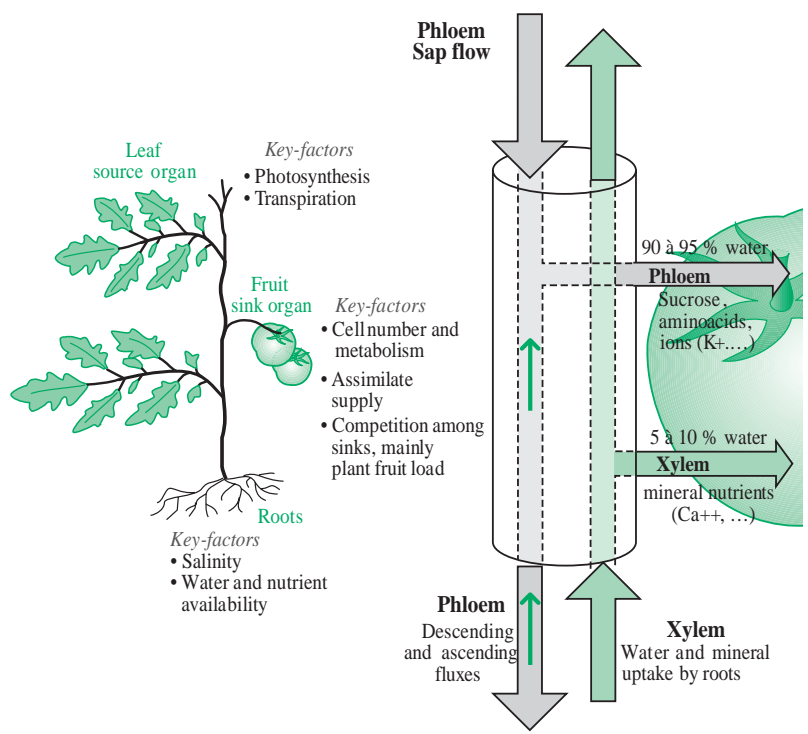

Figure 2. Main factors affecting the water and carbon fluxes from source organs to fruits in tomato plants.
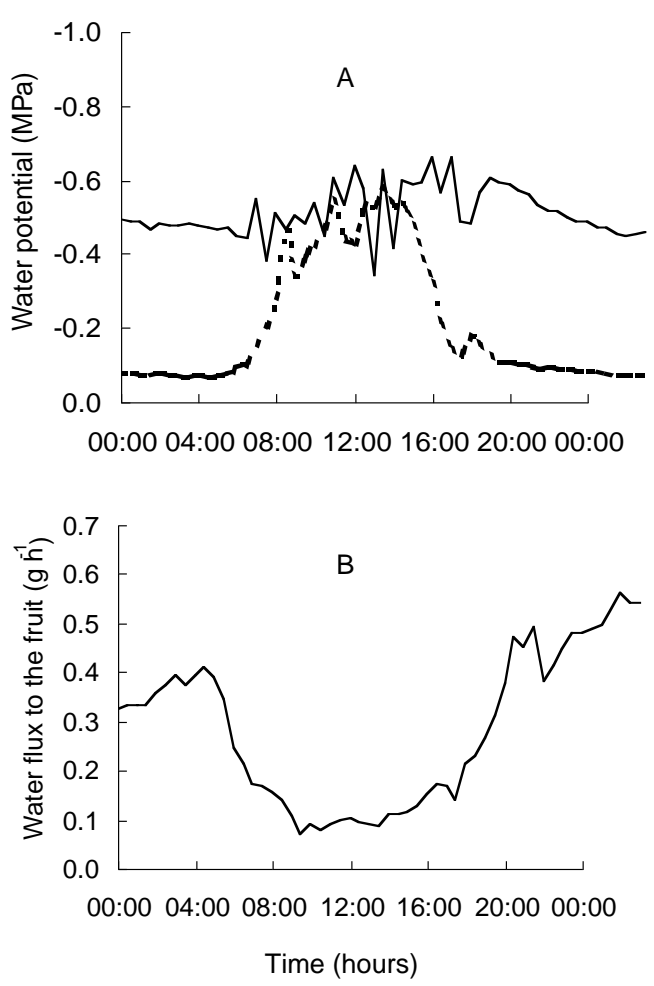

Figure 3. Time-course of water potential in tomato fruit ( - ) and in the closest stem internode (- ) (A), and of water flux in the fruit pedicel (B), during a 24-hour period in summer conditions [29]. Water potential was measured continuously with micropsychrometers, and water flux in the pedicel with the heat pulse method. 
humidity reduces the competition between the leaves and fruit for calcium and hence the occurrence of BER on the fruit.

Finally, Bertin et al. [13] showed that small fruit loads, also favourable to an increase in the size of fruit, lead to an increase in the occurrence of BER. These results are in agreement with those of Adams and Ho [6] who showed that the varieties which are susceptible to BER tend to have larger sized fruit. The occurrence of BER in conditions of small fruit loads and/or in the event of saline or water stress would seem to be due mainly to imbalances between the calcium requirements of the fruit during the rapid growth period (cell expansion) and the low calcium supply linked to environmental conditions and the intrinsic characteristics of the tomato fruit $[11,28,34,36,40,46]$.

\section{EFFECTS OF WATER AND CARBON FLUXES ON FRUIT CRACKING}

Fruit cracking is another aspect of fruit quality. The symptoms of this physiological disorder are the appearance of cracks covering varying areas of the proximal surface of fruit which make them unfit for sale.

The occurrence of netting and cracking corresponds to the loss of elasticity in the epidermis of the fruit. The fruit which are the most affected by cracking are those with an epidermis whose walls are thick and not extensible enough [59]. This lack of elasticity when the fruit expands considerably seems to cause the epidermis to break $[43,55]$. During the day, these cracks seem to form early in the morning or at the end of the afternoon [55], at times when the growth rate of the fruit as well as the sap flows are maximum $[28,56]$. Thus, the conditions which favour large growth spurts of the fruit are propitious to the appearance of cracks: for example abundant but infrequent irrigation [1], high day/night temperature differences or strong fluctuations in air humidity during the day [59]. Infrequent irrigation probably results in an alternation of high water flux entering the fruit (beginning and end of day when quantity of water supplied by irrigation is high) and episodes of low growth rate or even water efflux from the fruit and turgor loss (around midday) which would affect the epidermis elasticity. In the same way, temperature and humidity fluctuations would result in a succession of periods of high growth rate and of fruit shrinkage propitious to the occurrence of cracking.

Some studies showed that in summer misting is favourable to cracking $[13,49]$. The effect of low VPD on cracking could be explained by the fact that the growth rate of fruit is higher [28]. Misting especially during the hottest hours of the day seems to lead to a better water status of the plant (higher stem and leaf water potentials and lower plant transpiration), a lower transpiration of the fruit and an increase in the water and carbon fluxes entering the fruit, as fruit water potential remains steady and lower than stem water potential [29].

An increase of the leaf/fruit ratio [23] by thinning or using small fruit loads [9, 13] favours cracking. These results could be explained by the fact that these growing conditions change the source/sink balance of the plant leading to an increase in the supply of assimilates and water towards the fruit. The occurrence of cracking could also be considered through sugars metabolism. Cracks are visually perceptible on fruits six to seven weeks after fruit set in the last phase of fruit growth [9] whereas fruit starch is hydrolysed into fructose and glucose five weeks after fruit set [54]. The fruit osmotic potential might decrease consequently and result in a higher water flux into the fruit. The increase of internal turgor could lead to a higher pressure on the cell walls and then to a higher occurrence of cracking. This phenomenon combined with high growth rates (three to four weeks after fruit set) would increase the occurrence of cracking.

\section{CONCLUSIONS}

This review shows that it is now possible to understand and control certain aspects of fruit quality by taking into account the effect of cultural practices and environmental conditions on water and carbon fluxes imported by the fruit during its growth. For example, it is possible to produce ripe fruit with a high dry matter concentration by using more saline nutrient solutions or by applying a slight water stress to plants. In these conditions, the sugars imported by the fruit via the phloem become concentrated under the effect of a reduced water supply. However this technique has a setback in that it reduces the size and yield of the fruit. To release this contradiction, Ho and Grimbly [37] proposed increasing the number of fruit cells as well as their extension capacity. Nevertheless, the problem of BER would remain difficult to solve since the conditions which help increase dry matter and sugar concentration are also favourable to the onset of this disorder. Thus, calcium spraying on clusters would be a means of reducing BER without changing environmental conditions [30].

In the literature, the sugars (fructose and glucose) generally follow the time-course of dry matter in the fruit, which is logical since they originate from starch hydrolysis, the main form of assimilate storage [52]. Improving the sugar concentration of fruit (sucrose, 
starch or reducing sugars) could therefore be possible on condition that the mechanisms involved in their metabolism, partitioning and membrane transport are better understood [33]. On the other hand, little information is available in the literature on the acid contents in fruit. These have very seldom been dealt with from a functional point of view and the information available does not make it possible to include them in a schema of plant functioning in terms of water and carbon fluxes. This is also the case of all the compounds originating from the secondary metabolism of fruit such as volatile compounds or pigments.

We can hope that predictive models of fruit composition will soon be available as tools for managing quality. Such models have already been outlined for other species with dry matter and sugar concentrations of the fruit [24] or even acid concentration in peaches [50] as the main variables. In tomato, they are still being developed and depend largely on greater knowledge of the control and physiological mechanisms of the synthesis and storage of the different compounds of the fruit (acids, volatile compounds, vitamins, pigments).

Finally, even if it is now possible to explain the final tomato fruit quality better by taking into account the water and carbon fluxes imported by the fruit during its growth, some essential variables have still to be studied such as sugar concentration of the phloem sap, calcium concentration of xylem sap and their time-course during the day and fruit development for different environmental conditions.

Acknowledgements: The Conseil Régional Provence Alpes Côte d'Azur funded the project in the framework of which this review was carried out, and the Ph.D. fellowship of the first author. The authors are grateful to Christine Young for her translation of the manuscript into English.

\section{REFERENCES}

[1] Abbott J.D., Peet M.M., Willits D.H., Gough R.E., Water management of greenhouse tomatoes, HortScience 20 (1985) 688-690.

[2] Adams P., Effects of increasing the salinity of the nutrient solution with major nutrients or sodium chloride on the yield, quality and composition of tomatoes grown in rockwool, J. Hortic. Sci. 66 (1979) 201-207.

[3] Adams P., Effects of increasing the salinity of the nutrient solution with major nutrients or sodium chloride on the yield, quality and composition of tomatoes grown in rockwool, J. Hortic. Sci. 66 (1991) 201-207.

[4] Adams P., El-Gizawy A.M., Effect of salinity and watering level on the calcium content of tomato fruit, Acta Hort. 190 (1986) 253-259.
[5] Adams P., Ho L.C., Effects of constant and fluctuating salinity on the yield, quality and calcium status of tomatoes, J. Hortic. Sci. 64 (1989) 725-732.

[6] Adams P., Ho L.C., The susceptibility of modern tomato cultivars to BER in relation to salinity, J. Hortic. Sci. 67 (1992) 827-839.

[7] Adams P., Ho L.C., Effects of environment on the uptake and distribution of calcium in tomato and on the incidence of blossom-end rot, Plant and Soil 154 (1993) 127-132.

[8] Adams P., Holder R., Effects of humidity, Ca and salinity on the accumulation of dry matter and $\mathrm{Ca}$ by the leaves and fruit of tomato (Lycopersicon esculentum), J. Hortic. Sci. 67 (1992) 137-142.

[9] Bakker J.C., Russeting (cuticle cracking) in glasshouse tomatoes in relation to fruit growth, J. Hortic. Sci. 63 (1988) 459-463.

[10] Belda R.M., Ho L.C., Salinity effects on the network of vascular bundles during tomato fruit development, J. Hortic. Sci. 68 (1993) 557-564.

[11] Belda R., Fenlon J.S., Ho L.C., Salinity effects on the network of vascular bundles during tomato fruit development, J. Hortic. Sci. 68 (1996) 557-564.

[12] Bertin N., Heuvelink E., Dry matter production in tomato crop: comparison of two simulation models, J. Hortic. Sci. 68 (1993) 995-1011.

[13] Bertin N., Guichard S., Leonardi C., Longuenesse J.-J., Langlois Y., Navez B., Seasonal evolution of quality of fresh glasshouse tomatoes under Mediterranean conditions, as affected by air vapour pressure deficit and plant fruit load, Ann. Bot. 85 (2000) 741-750.

[14] Blanc D., The influence of cultural practises on the quality of the production in protected cultivation with special references to tomato production, Acta Hort. 191 (1986) 85-98.

[15] Buret M., Duprat F., Étude de la qualité de la tomate. Approche méthodologique et influence des systèmes de culture, in: Blanc D. (Ed.), Les cultures hors sol, ATP de l'INRA, INRA, Paris, 1985, pp. 361-387.

[16] Czarnowski M., Starzecki W., Spectral properties and $\mathrm{CO}_{2}$ exchange of tomato fruits, Photosynthetica 27 (1992) 513-519.

[17] Davies J.N., Hobson G.E., The constituents of tomato fruit - the influence of environment, nutrition and genotype, Crit. Rev. Food Sci. Nutr. 15 (1981) 205-280.

[18] Davies J.N., Maw G.A., Metabolism of citric and malic acids during ripening of tomato fruit, J. Sci. Food Agric. 23 (1972) 969-979.

[19] Dorais M., Dorval R., Demers D.A., Micevic D., Turcotte G., Hao X., Papadopoulos A.P., Erhet D.L., Gosselin A., Improving tomato fruit quality by increasing salinity: effects on ion uptake, growth and yield, Acta Hort. 511 (2000) 185-196.

[20] Erhet D.L., Ho L.C., Effects of osmotic potential in nutrient solution on diurnal growth of tomato fruit, J. Exp. Bot. 37 (1986) 1294-1302. 
[21] Erhet D.L., Ho L.C., Effects of salinity on dry matter partitioning and fruit growth in tomato grown in nutrient film culture, J. Hortic. Sci. 61 (1986) 361-367.

[22] Erhet D.L., Ho L.C., Translocation of calcium in relation to tomato fruit growth, Ann. Bot. 58 (1986) 679-688.

[23] Erhet D.L., Helmer T., Hall J.W., Cuticle cracking in tomato fruit, J. Hortic. Sci. 68 (1993) 195-201.

[24] Fishman S., Génard M., A biophysical model of fruit growth: simulation of seasonal and diurnal dynamics of mass, Plant Cell Environ. 21 (1998) 739-752.

[25] Gough C., Hobson G.E., A comparison of the productivity, quality, shelf-life characteristics and consumer reaction to the crop from cherry tomato plants grown at different levels of salinity, J. Hortic. Sci. 65 (1990) 431-439.

[26] Grange R.I., Andrews J., Expansion rate of young tomato fruit growing on plants at positive water potential, Plant Cell Environ. 17 (1994) 181-187.

[27] Grierson D., Kader A.A., Fruit ripening and quality, in: Atherton, Rudish (Eds.), The tomato crop, Chapman and Hall, London, 1986, pp. 241-280.

[28] Guichard S., Flux hydriques, croissance et qualité du fruit de tomate (Lycopersicon esculentum Mill.) en conditions estivales sous serre, Thesis, Université d'Aix-Marseille, France, 1999.

[29] Guichard S., Gary C., Longuenesse J.-J., Leonardi C., Water fluxes and growth of greenhouse tomato fruits under summer conditions, Acta Hort. 507 (1999) 223-230.

[30] Hao X., Papadopoulos A.P., Dorais M., Erhet D.L. Turcotte G., Gosselin A., Improving tomato fruit quality by raising the EC of NFT nutrient solutions and calcium spraying: effects on growth, photosynthesis, yield and quality, Acta Hort. 511 (2000) 213-221.

[31] Heuvelink E., Tomato growth and yield: a quantative analysis and synthesis, Thesis, Wageningen Agricultural University, Netherlands, 1996.

[32] Ho L.C., Environmental effects on the diurnal accumulation of ${ }^{45} \mathrm{Ca}$ by young fruit and leaves of tomato plants, Ann. Bot. 63 (1989) 281-288.

[33] Ho L.C., Tomato, in: Zamski E., Schaffer A.A. (Eds.), Photoassimilate distribution in plants and crops: Source-sink relationships, Dekker M. Inc, New York, 1996, pp. 709-728.

[34] Ho L.C., Improving tomato fruit quality by cultivation, in: Cockshull K.E., Gray D., Seymour G.B., Thomas B. (Eds.), Genetic and Environmental Manipulation of Horticultural Crops, CAB International, 1998, pp. 17-30.

[35] Ho L.C., Adams P., The physiological basis for high fruit yield and susceptibility to calcium deficiency in tomato and cucumber, J. Hortic. Sci. 69 (1994) 367-376.

[36] Ho L.C., Adams P., Nutrient uptake and distribution in relation to crop quality, Acta Hort. 396 (1995) 33-44.

[37] Ho L.C., Grimbly P., The physiological basis for tomato quality, Grower 22 (1990) 33-36.

[38] Ho L.C., Hewitt J.D., Fruit development, in: Atherton, Rudish (Eds.), The tomato crop, Chapman and Hall, London, 1986, p. 208.
[39] Ho L.C., Grange R.I., Picken A.J., An analysis of the accumulation of water and dry matter in tomato fruit, Plant Cell Environ. 10 (1987) 157-162.

[40] Ho L.C., Belda R., Brown M., Andrews J., Adams P., Uptake and transport of calcium and the possible causes of blossom-end rot in tomato, J. Exp. Bot. 44 (1993) 509-518.

[41] Hobson G.E., Bedford L., The composition of cherry tomatoes and its relation to consumer acceptability, J. Hortic. Sci. 64 (1989) 321-329.

[42] Johnson R.W., Dixon M.A., Lee D.R., Water relations of tomato during fruit growth, Plant Cell Environ. 15 (1992) 947-953.

[43] Kamimura S., Yoshikawa H., Ito K., Studies on fruit cracking in tomatoes, Bull. Hortic. Res. Station Morioka, Iwate Japan 7 (1972) 7-138.

[44] Kitano M., Yokomakura F., Eguchi H., Interactive dynamics of fruit and stem growth in tomato plants as affected by root water condition I. Expansion and contraction of fruit and stem, Biotronics 25 (1996) 67-75.

[45] Kitano M., Yokomakura F., Eguchi H., Interactive dynamics of fruit and stem growth in tomato plants as affected by root water condition II. Relation with sucrose translocation, Biotronics 25 (1996) 77-84.

[46] Lee D.R., Vasculature of the abscission zone of tomato fruit: implications for transport, Can. J. Bot. 67 (1989) 1898-1902.

[47] Lee D.R., Dixon M.A., Johnson R.W., Simultaneous measurements of tomato fruit and stem water potentials using in situ stem hygrometers, Can. J. Bot. 67 (1989) 2352-2355.

[48] Leonardi C., Baille A., Guichard S., Effects of fruit characteristics and climatic conditions on tomato transpiration in greenhouse, J. Hortic. Sci. Biotechnol. 74 (1999) 748-756.

[49] Leonardi C., Guichard S., Bertin N., High vapour pressure deficit influences growth, transpiration and quality of tomato fruits, Sci. Hortic. 1458 (1999) 1-12.

[50] Lobit P., Étude et modélisation de l'acidité des pêches (Prunus persica L. Batsch, cv. Fidelia), Application à l'étude des effets de la nutrition azotée, Thesis, ENSA Montpellier, France, 1999.

[51] Malundo T.M.M., Shewfelt R.L., Scott J.W., Flavor quality of fresh tomato (Lycopersicon esculentum Mill.) as affected by sugar and acid levels, Postharvest Biol. Technol. 6 (1995) 103-110.

[52] Marcelis L.F.M., Simulation of plant-water relations and photosynthesis of greenhouse crops, Sci. Hortic. 41 (1989) 9-18.

[53] Mars S., Otto C., Blanc D., La qualité de la tomate. Influence de la nature du substrat et de la nutrition, in: Blanc D. (Ed.), Les cultures hors sol, ATP de l'INRA, INRA, Paris, 1985, pp. 347-359.

[54] Mitchell J.P., Shennan C., Grattan S.R., Developmental changes in tomato fruit composition in response to water deficit and salinity, Physiol. Plant. 83 (1991) 177-185.

[55] Ohta K., Hosoki T., Matsumoto K., Ohya M., Ito N., Inaba K., Relationships between fruit cracking and changes of 
fruit diameter associated with solute flow to fruit in cherry tomatoes, J. Jpn. Soc. Hortic. Sci. 65 (1997) 753-759.

[56] Sakiyama R., Stevens M.A., Organic acid accumulation in attached and detached tomato fruits, J. Am. Soc. Hortic. Sci. 101 (1976) 394-496.

[57] Stevens M.A., Kader A.A., Albright M., Potential for increasing tomato flavor via increased sugar and acid content, J. Am. Soc. Hortic. Sci. 104 (1979) 40-42.

[58] Van Goor B.J., Influence of restricted water supply on blossom-end rot and ionic composition of tomatoes grown in nutrient solution, Comm. Soil Sci. Plant Anal. 5 (1974) 13-24.
[59] Wacquant C., Microfissures ou rugosité des fruits de la tomate, Ctifl, Centre de Balandran, France, 1995, 4 p.

[60] Walker A.J., A study of the mechanism of unloading in the tomato fruit in relation to the rate of translocation of leaf assimilates, Thesis, Sussex University, UK, 1975.

[61] Winsor G.W., Adams P., Changes in the composition and quality of tomato fruit throughout the season, Annual Report. Glasshouse Crops Research Institute 1975 (1976) 134-142.

[62] Wolterbeek H.Th., Willemse P.C.M., van Die J., Phloem and xylem import of water and solutes in tomato fruits, Acta Bot. Neerl. 36 (1987) 295-306. 